\title{
Flashing lights to deter small stock depredation in communal farmlands of Namibia
}

\author{
Stijn Verschueren ${ }^{1 *}$, Carolina Torres-Uribe ${ }^{1}$, Willem D. Briers-Louw ${ }^{1}$, Gabriela Fleury $^{1}$, Bogdan Cristescu ${ }^{1,2} \&$ Laurie Marker $^{1}$ \\ ${ }^{1}$ Ecology Department, Cheetah Conservation Fund, Otjiwarongo, Namibia \\ 2Department of Agriculture and Natural Resources Sciences, Namibia University of Science and Technology, Windhoek, Namibia
}

*corresponding author: stijn@cheetah.org

DOI: https://doi.org/10.52201/CEJ18VQFL3817

SUMMARY: Flashing lights can work as an effective visual deterrent to protect livestock in kraals at night against wild carnivores.

\section{BACKGROUND}

Non-lethal conflict mitigation strategies are key to promoting human-wildlife coexistence and a wide range of technical approaches exist (Breitenmoser et al. 2005, Littlewood et al. 2020). One of many techniques is the use of flashing lights as a visual repellent that may mimic human activity to deter wildlife. This technique has largely been proven effective in protecting livestock from depredation by carnivores at night (Lesilau et al. 2018, Ohrens et al. 2019, Okemwa et al. 2018, Naha et al. 2020, Sutherland et al. 2021, Wanjira et al. 2021). Yet without reinforcement with aversive human activity, such as lethal control, the efficacy of flashing lights as a visual deterrent may be limited (Hall \& Flemming 2021). We investigated the effect of lights on small-stock (sheep/goats) depredation in communal livestock farmlands of eastern Namibia $\left(\mathrm{S} 20.477837^{\circ}, \mathrm{E} 18.309661^{\circ}\right)$. The primary predators of small stock are black-backed jackal Canis mesomelas and caracal Caracal caracal, which are highly persecuted (Verschueren et al. 2020). This study increases the geographic scope of current knowledge and adds to the evidence base for using flashing lights as an effective method for reducing human-wildlife conflict.

\section{ACTION}

We selected five farmers who reported small-stock losses to carnivore attacks within kraals ( $12 \mathrm{~m}$ x $12 \mathrm{~m}$ enclosure). Kraaling is a culturally accepted method of livestock confinement at night to reduce carnivore conflict, yet size, shape and maintenance of kraals is important for their effectiveness (Weise et al. 2018). Reported losses were attributed primarily to jackal and infrequently to cheetah Acinonyx jubatus, that farmers were able to differentiate consistently based on bite marks on livestock, tracks and scat; as well as unknown carnivores that they were unable to identify. We equipped farmers with four Foxlights ${ }^{\circledR}$ (Bexley North, Australia), to place one on each side of the kraals $(n=5)$. Foxlights are solar-powered devices that emit randomly varying, flashing lights in three colours (red, blue, and green), with the light emission triggered by a sensor that detects darkness (Figure 1). At time of deployment, we recorded the number of small stock owned, the number of small stock lost to carnivores in the previous year, the location where the attack occurred (within kraal, < $15 \mathrm{~m}$ from kraal, $>15 \mathrm{~m}$ from kraal), and time when the attack occurred (day, night). One year after deployment, we conducted a follow-up survey asking the same questions. The study ran from December 2018 to December 2019.

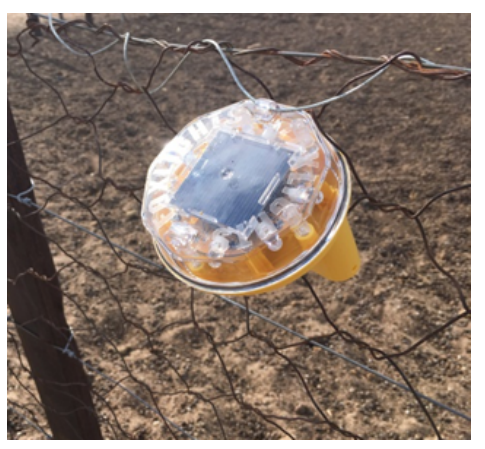

Figure 1. Foxlight deployed on the fence of a kraal.

\section{CONSEQUENCES \& DISCUSSION}

After the deployment of Foxlights, no livestock were lost to carnivores at night, inside the kraal, or within $15 \mathrm{~m}$ of the kraal during the study period (Table 1). Livestock losses away from the kraal were attributed to cheetah and serval Leptailurus serval, although the latter was most likely caracal being misidentified by farmers. Our results suggest that flashing lights could work as an effective visual deterrent to protect livestock in kraals against nocturnal carnivores. We left the Foxlights with the farmers and other farmers in the area have replicated the technique. This provides an opportunity for long-term monitoring of the effectiveness of flashing lights as previous studies found reduced effectiveness due to habituation and location shifts of conflict cases (Darrow \& Shivik 2009, Lesilau et al. 2018). We recommend the use of flashing lights as part of a more complex and integrative livestock management plan that targets long-term humancarnivore coexistence.

Table 1. Summary of small-stock numbers before and after installation of Foxlights.

\begin{tabular}{|c|c|c|c|c|c|c|c|c|c|}
\hline \multirow{2}{*}{ Treatment } & \multirow{2}{*}{$\begin{array}{l}\text { Farmers } \\
\text { with } \\
\text { losses }\end{array}$} & \multirow{2}{*}{$\begin{array}{l}\text { Total small } \\
\text { stock } \\
\text { owned }\end{array}$} & \multirow{2}{*}{$\begin{array}{l}\text { Total } \\
\text { small } \\
\text { stock lost } \\
\end{array}$} & \multirow{2}{*}{$\begin{array}{l}\text { Loss per } \\
\text { farmer } \\
( \pm \text { SD }) \\
\end{array}$} & \multicolumn{3}{|c|}{ Location relative to kraal } & \multicolumn{2}{|c|}{ Time } \\
\hline & & & & & Inside & $<15 \mathrm{~m}$ & $>15 \mathrm{~m}$ & Day & Night \\
\hline Before & 5 & 338 & 36 & $7( \pm 3)$ & 25 & 5 & 6 & 11 & 25 \\
\hline After & 2 & 385 & 15 & $3( \pm 5)$ & 0 & 0 & 15 & 15 & 0 \\
\hline
\end{tabular}




\section{ACKNOWLEDGEMENTS}

AGA Aktionsgemeinshaft Artenshutz and Ian Whalan, inventor of Foxlights, donated Foxlight devices.

\section{REFERENCES}

Breitenmoser, U., Angst, C., Landary, J.-M., Breitenmoser-Würsten, C., Linnell, J.D.C. \& Weber, J.-M. (2005) Non-lethal techniques for reducing depredation. Pages 49-71 in: R. Woodroffe, S. Thirgood, \& A. Rabinowitz (eds.) People and wildlife: Conflict or coexistence? Cambridge University Press, Cambridge.

Darrow, P.A. \& Shivik, J.A. (2009) Bold, shy, and persistent: Variable coyote response to light and sound stimuli. Applied Animal Behaviour Science, 116, 82-87. https://doi.org/10.1016/J.APPLANIM.2008.06. 013

Hall, K. J. \& Fleming, P. A. (2021) In the spotlight: Can lights be used to mitigate fox predation on a free-range piggery? Applied Animal Behaviour Science, 242, 105420. https://doi.org/10.1016/J.APPLANIM.2021.105 420

Lesilau, F., Fonck, M., Gatta, M., Musyoki, C., van 't Zelfde, M., Persoon, G.A., Musters, K.C.J.M., de Snoo, G.R. \& De Iongh, H.H. (2018) Effectiveness of a LED flashlight technique in reducing livestock depredation by lions around Nairobi National Park, Kenya. PLoS ONE, 13, e0190898. https://doi.org/10.1371/journal.pone.0190898

Littlewood, N.A., Rocha, R., Smith, R.K., Martin, P.A., Lockhart, S.L., Schoonover, R.F., Wilman, E., Bladon, A.J. Sainsbury, K.A., Pimm, S. \& Sutherland W.J. (2020) Terrestrial Mammal Conservation: Global evidence for the effects of interventions for terrestrial mammals excluding bats and primates. Open Book Publishers, Cambridge. https://doi.org/10.11647/OBP.0234
Naha, D., Chaudhary, P., Sonker, G. \& Sathyakumar, S. (2020) Effectiveness of nonlethal predator deterrents to reduce livestock losses to leopard attacks within a multiple-use landscape of the Himalayan region. PeerJ, $\mathbf{8}$, e9544. https://doi.org/10.7717/peerj.9544

Ohrens, O., Bonacic, C. \& Treves, A. (2019) Nonlethal defense of livestock against predators: flashing lights deter puma attacks in Chile. Frontiers in Ecology and the Environment, 17, 32-38. https://doi.org/10.1002/fee.1952

Okemwa, B., Gichuki, N., Virani, M., Kanya, J., Kinyamario, J. \& Santangeli, A. (2018) Effectiveness of LED lights on bomas in protecting livestock from predation in southern Kenya. Conservation Evidence, 15, 39-42.

Sutherland, W.J., Dicks, L.V., Petrovan, S.O., \& Smith, R.K. (2021) What Works in Conservation. Open Book Publishers, Cambridge. https://doi.org/10.11647/OBP.0267

Verschueren, S., Briers-Louw, W.D., Torres-Uribe, C., Siyaya, A. \& Marker, L. (2020) Assessing human conflicts with carnivores in Namibia's eastern communal conservancies. Human Dimensions of Wildlife, 25, 452-467. https://doi.org/10.1080/10871209.2020.175825 3

Wanjira, J., Ndiwa, T.C., Gichuki, N. \& Wykstra, M. (2021) Evaluating the efficacy of flashing lights in deterring livestock attacks by predators: a case study of Meibae Community Conservancy, Northern Kenya. East African Journal of Science, Technology and Innovation, 2, 1-18. https://doi.org/10.37425/EAJSTI.V2I3.303

Weise, F.J., Hayward, M.W., Aguirre, R.C., Tomeletso, M., Gadimang, P., Somers, M.J. \& Stein, A.B. (2018) Size, shape and maintenance matter: A critical appraisal of a global carnivore conflict mitigation strategy - Livestock protection kraals in northern Botswana. Biological Conservation, 225, 88-97. https://doi.org/10.1016/j.biocon.2018.06.023

The Conservation Evidence Journal is an open access online journal devoted to publishing the evidence on the effectiveness of management interventions. The other papers from The Conservation Evidence Journal are available from www.conservationevidencejournal.com. The pdf is free to circulate or add to other websites and is licensed under the Creative Commons Attribution 4.0 International License http://creativecommons.org/licenses/by/4.0/. Under this licence, authors retain ownership of the copyright for their articles. 